\title{
Water Sector Service Innovation: What, Where and
}

\author{
Sarah Ward ${ }^{1 *}$, Steve Brown ${ }^{2}$, Aaron Burton ${ }^{3}, K_{\text {Kemi Adeyeye }}^{4}$, Noel Mannion ${ }^{5}$, \\ Siraj Tahir ${ }^{6}$, Craig Gordon ${ }^{7}$ and George Chen ${ }^{8}$ \\ ${ }^{1}$ Centre for Water Systems, University of Exeter, UK. \\ ${ }^{2}$ Centre for Environmental Strategy, University of Surrey, UK \\ ${ }^{3}$ Waterwise, UK \\ ${ }^{4}$ University of Bath/WATEF, UK. \\ ${ }^{5}$ Mace Group, UK. \\ ${ }^{6}$ University College London (UCL), UK. \\ ${ }^{7}$ Oxford Innovation, UK. \\ ${ }^{8}$ Heriot-Watt University, Scotland.
}

\begin{abstract}
Authors' contributions
This work was carried out in collaboration between all authors, who co-designed the study together. Each author undertook some form of data collection. Authors SW and SB analysed the data with input from author $A B$. Authors $S W$ and $S B$ wrote the manuscript with contributions and revisions by author $A B$. All authors read, commented on and approved the final manuscript.
\end{abstract}

Article Information

DOI: 10.9734/BJECC/2016/23730

Original Research Article

Received $18^{\text {th }}$ December 2015

Accepted $11^{\text {th }}$ June 2016

Published 25 ${ }^{\text {th }}$ August 2016

ABSTRACT

Aims: Changes in water law and policy, in the UK and further afield, are promoting social and service innovation, as well as technical innovation in the water sector. In particular, the separation of wholesale and retail water and sewerage services for English and Welsh commercial water systems customers is leading to a focus on service innovation. But what do we mean by 'service innovation'? To whom does it apply and how do these parties interpret it? To answer these questions, this paper presents the findings of recent interviews undertaken by and case studies presented to the Water Efficiency (WATEF) Network Service Innovation Technical Committee.

Study Design: The paper explores definitions and interpretations of service innovation (SI) and discusses case studies where SI is already being realised in the water sector.

Methodology: The study was conducted using interviews and case studies.

Results: A tree-branch model of SI is proposed, emphasising the placement of the customer as the focus of SI. A revised definition of SI was also provided to assist water service providers in enhancing the services provided to their customers. 
Conclusion: The study revealed that the water sector offers scope for improvement in fundamental business services. These include billing, customer relations, communication (information services) and data provision and visualisation.

Keywords: Change; client; concept; delivery; service innovation; technology; water efficiency.

\section{INTRODUCTION}

The Water Act received Royal Assent on $14^{\text {th }}$ May 2014 [1], ushering in wholesale and retail separation and opportunities for non-domestic (business) customers to change their supplier. Previously only the largest water users in England and Wales could switch suppliers. However, the process of deregulation will take place between 2014 and 2017, when all nondomestic customers will theoretically be able to switch water service providers (WSPs). In the context of this deregulated water market, WSPs are becoming more focussed on recruiting new, and retaining existing customers. According to Ofwat (the financial regulator) it is unlikely that the unit cost of water between water companies will be a large enough differential to encourage organisations to switch their provider [2]. For example, in Scotland, where the water market is already deregulated, a significantly higher proportion of eligible customers negotiated deals with their existing supplier rather than changing to a new one. However, participants in recent CCWater (consumer body) research highlighted there was limited information available on the percentage of savings or value added services in such renegotiation cases [3]. Another case where deregulation may be enacted differently or produce different results is where a company's business model may vary. This is exemplified by Dŵr Cymru Welsh Water, which operates in the majority of Wales, and is owned by a single private company limited by guarantee (i.e. without shareholders) - therefore it is able to retain financial surpluses to reinvest into company activities. This is in contrast to the other nine regulated water and sewerage companies in England and Wales, which are private companies with shareholders to whom they must pay dividends [4]. Finally, recent changes to the regulatory regime have introduced outcome delivery incentives or so-called 'ODIs, which include industry-wide and WSP-specific targets. The ODIs focus on performance commitments and associated incentives (or penalties) as opposed to purely capital inputs or measures. Use of ODls in the energy sector has successfully led some service providers to reorganise with a focus on the delivery of regulatory promises through managing their business differently. Whether or not this will have similar impact in the water sector and what it means for service innovation will be seen in the next asset management planning period (AMP6) [5].

Within the Water Act a number of measures are highlighted as potentially catalysing change: price limits, social tariffs, WaterSure (for lowincome customers), water metering and concessionary schemes for surface water drainage charges. In the past, the variability of service across more than 22 WSPs has led to non-standardised billing, customer service dissatisfaction and high cost transactions (time and money). As previously mentioned, nondomestic customers in Scotland are already within a deregulated market where, according to Ofwat, efficiencies have been made by standardising and improving certain aspects of service provision [2]. But has deregulation led to service innovation? And what is meant by this term? Innovation is broadly defined by Ofwat as the application of new technology, business processes or management expertise that delivers any improvements to customer service, the environment or cost efficiency. However, "Service Innovation" within the context of the UK water industry is widely discussed but often not defined further. More generally this has been broken down into innovation around service products, service processes and service organisational change. The need for a definition emerges in order to benchmark whether different options are indeed innovative and servicefocused. Without at least a working definition, almost anything could be deemed SI, which would not facilitate useful assessment of how WSPs are performing [2].

\subsection{Definitions of Service Innovation}

First documented in 1993 by Miles [6], service innovation (SI) as a concept began by characterising the features of services associated with innovation, usually of a technological or expertise-based product. This early research covered innovation in services, products, processes and firms (organisations and 
industry) and was broader than just looking at the novel aspects of the services themselves. A useful typology of SI was elaborated by [7] and is illustrated in Fig. 1. The four dimensions of den Hertog and Bilderbeek's typology represent the SI concept, the client, the delivery system and technological options. Further to this, Van Ark et al. [8] proposed the following definition of SI: "a new or considerably changed service concept, client interaction channel, service delivery system or technological concept that individually, but most likely in combination, leads to one or more (re)new(ed) service functions that are new to the firm and do change the service/good offered on the market and do require structurally new technological, human or organizational capabilities of the service organization".

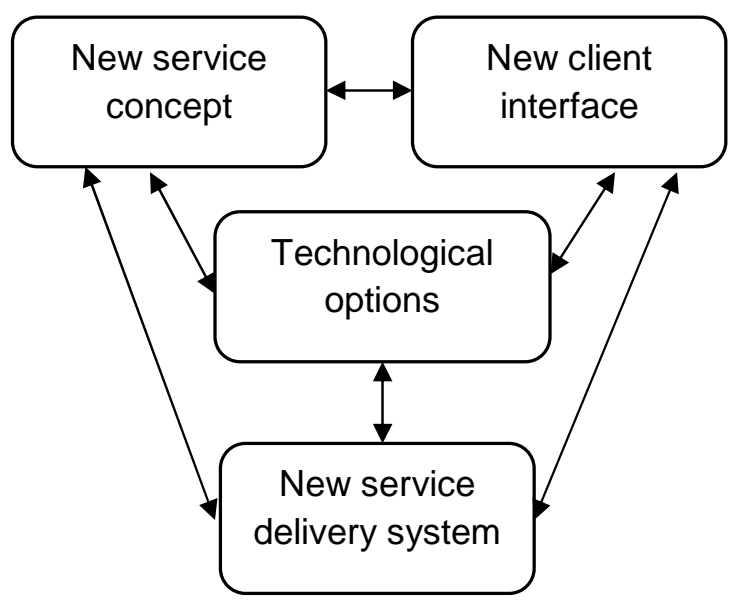

Fig. 1. A four dimensional typology of service innovation (adapted from [7])

With regard to small to medium enterprises (SMEs), the European Commission [9] sees SI as having transformative (disruptive) powers in relation to economic change and as being a catalyst of cross-sectoral enrichment and new business models. Similarly to the aforementioned definition by [8], the EC defines SI as comprising: "...new or significantly improved service concepts and offerings as such, irrespective of whether they are introduced by service companies or manufacturing companies, as well as innovation in the service process, service infrastructure, customer processing, business models, commercialisation (sales, marketing, delivery), service productivity and hybrid forms of innovation serving several user groups in different ways simultaneously." The EC goes on to elaborate on its definition of transformative power, by asserting that SI should enhance customer experience by disrupting existing channels to market, processes and models, acting on the whole value chain. Consequently, emerging sectors, industries and markets are shaped influencing modernisation and change at the activity concept, company client, sectoral system and market levels. Ten 'dos' and 'don'ts' in relation to SI are suggested, which include:

- Don'ts: focusing purely on research and technological innovation, supporting individual specialised firms, copy-pasting best practice, following without reflecting, not having specific targets, launching pilots in isolation, match a problem to an innovation;

- Do's: focusing on all knowledge and innovation, support transformation, support firm clusters and networks, focus on manufacturing and services, search for next best practice, capitalise on regional competencies, be systemic and cross-sectoral, launch large-scale demonstrations, match an innovation to a problem.

Additionally, ideas for support instruments include:

- For companies: innovation clinics/ incubation centres, vouchers, management guidance, access to finance;

- For sector: design centres, living labs, cluster support and assistance;

- For market: awareness raising, cooperation incentives, vouchers, procurement initiatives.

Whilst these have been developed with SMEs as a focus, it is asserted that they could be useful at other levels and across a range of sectors via the 'spill-over' effect (where events in one context occur because of events in a seemingly unrelated context). The EC definition fits well within den Hertog and Bilderbeek's 4D typology and therefore this research uses the typology as a framework for considering SI by WSPs in England under deregulation.

A sector in which deregulation has taken place includes the energy sector, where deregulation has resulted in realignment from a cost-based to performance-based focus considering satisfaction and security of supply [10]. Innovation to services for domestic (residential) customers have included information services (receiving consumption information by email, 
digital TV or instant message to a mobile phone), consumption simulation (to estimate future demand based on a range of practices), smart measurement (metering, monitoring and response), smart control and delegation (whereby customers enable their retailer to electronically control their equipment (e.g. white goods) to reduce consumption), roaming (customer can access the system via an 'app') and payment (wide variety of environmentindependent options incorporating customer preferences). Whilst the energy sector has seen a range of service innovations, there is still some cynicism from non-household customers as to whether its use in the water sector will be beneficial or costly and whether regulation will be reintroduced at some future instance [3].

\subsection{A Working Definition of Service Innovation for Water Efficiency}

With the previously outlined options and typology in mind, the research presented in this paper was undertaken to develop an understanding of what SI could look like for the water sector and the types of options WSPs could consider offering to their customers. The paper forms part of the annual report of the Water Efficiency (WATEF) Network's Service Innovation Technical Committee (SITC), which is tasked with scoping:

- Retail competition service innovation for water efficiency;

- Innovative approaches to delivering services with customers and considering aspects such as the hydro-social contract and who is thought to be responsible for water efficiency delivery and messaging;

- Delivering partnership working for water efficiency (energy and social housing retrofit programmes - lessons learned, extent of implementation, further roll-out);

- Ensuring water efficiency is part of wider integrated service innovation such as Water Sensitive Cities.

This paper focuses on the first two objectives and proceeds as follows. The next section outlines the data collection and analysis methods used to refine the working definition of SI presented below. The following section presents the results and a discussion that recontextualises the findings in relation to the literature presented. A final conclusion section reiterates the main themes of the paper. Based on the literature presented above and discussions held at WATEF SITC meetings, the following working definition of SI for water efficiency is considered within the research presented in this paper: "Service innovation for water efficiency represents the concepts, clients, delivery systems and technological options available to the water sector through which to develop new or improved service functions resulting in an enhanced customer experience and requiring structural organisational change".

\section{METHODOLOGY}

In order to test and refine the working definition of service innovation for water efficiency (SIfWE) and gain insight into how SIfWE is perceived within the water sector, a mixed methods approach comprising the following data collection methods was utilised:

1. Links to an online questionnaire-based survey form and separate case study template form were circulated to WATEF SITC member's networks;

2. Informal semi-structured interviews were held with experts in the field of water management either in person or by phone, with notes taken, which were anonymised to comply with standard ethical practice.

The online case study template form consisted of 8 questions (7 open, 1 closed) regarding the participant's SIfWE initiative. The closed question consisted of a list of types of service innovation, from which the participant was invited to match their initiative to a type. The types listed were: pricing, inset, competition, rental/lease agreement, partnership, target, technical, service, research, asset delivery, customer engagement and other. These types were developed a priori by the WATEF SITC, not as an exhaustive prescriptive list, but to guide participants in thinking about how they would categorise their initiative. The open questions orientated around the features of the initiative, such as its name, how long it had been in operation (or if not yet operating, when the concept was first registered), the outcomes of the initiative (such as costs, water savings and wider benefits), ongoing monitoring, partnerships and dissemination. The interview pro forma consisted of an introductory section on the context of the Water Act and deregulation, followed by questions regarding reimagining service models for water provision and examples of SI from other sectors. Questions were designed to help prompt and funnel the participant into suggesting a definition of SI. For each data gathering method participants gave their informed consent for any information provided to be used in an analysis to 
be presented in this paper. The information gathered was triangulated [11] into the analysis that follows in order to refine the working definition of SIfWE.

\section{RESULTS AND DISCUSSION}

In total the details of five SI initiatives were registered by participants through the online case study template, four interviews were held with water management experts and only two participants completed the questionnaire. The low participation rate, particularly for the questionnaire, could be explained by a current lack of understanding regarding what comprises SIfWE or participants were constrained by not being able to find time to submit their information. A further explanation could be that of 'innovation protectionism', a concept that emerged from the data and that is explained in more detail later in this section. In compliance with standard ethical practice, the interviewees' anonymity is maintained. However, to place their comments into perspective, it is possible to note that they are senior figures in the water sector, across organisations such as water companies, research establishments, consultancies and associations.

\subsection{Service Innovation for Water Efficiency - Initiatives}

The real and hypothetical initiatives described by case study and interview participants are summarised in Table 1 and represent a small snapshot of the types of SIfWE that could be or are already in practice. Interview discussions across all the participants are summarised for each question in the following short sub-sections.

\subsubsection{Q1. What do you imagine could be an alternative service model to maximise water efficiency (WE)?}

Some participants suggested an alternative model where WSPs do not operate in silos, but facilitate water management in an integrated and holistic approach. Also, a new method of financing water efficiency projects to offset the low cost of water was highlighted. In contrary to this view, one participant suggested that water efficiency in a retail market is counterproductive and WSPs will be reluctant to maximise water efficiency. However, overall, participants agreed that the existing service model of water supply and treatment is very good.
3.1.2 Q2. Thinking about other services where you are free to choose your provider, such as gas and electricity, can you think of examples of ways organisations operate their services that you consider to be innovative?

Energy and Gas suppliers were cited as examples of innovative organisations with strong parallels to the water sector. All participants suggested that WSPs should look to energy companies for inspiration and direction with innovative schemes such as green tariffs, providing water monitoring equipment at no cost to the customer, improved communication channels, shorter billing cycles and on-demand water usage data available. However, one participant expressed a strong view that for the WSPs: "...innovation is a million miles away" and they should focus on getting the basics right, such as correct billing, before attempting to be innovative. The same participant also suggested that WSPs should look at any Business to Business (B2B) retail operation for guidance on the basics of business.

\subsubsection{Q3. Water is a key ingredient of life, and} yet most take this precious resource for granted. If you had to reinvent the way water is sold, distributed and valued as resource: what would it look like?

A common sentiment was that WSPs perform their water treatment and supply operations to a very high standard and overall run the water network exceptionally well. Therefore reinvention of the water supply system is not particularly useful or needed. However, one participant suggested this effective and centralised supply system also serves to perpetuate an emotional disconnect between the water from a tap and the source of the water. In a similar vein, the same participant asserted that the use of potable water for sanitation purposes (toilet flushing etc.) would not prevail in a reinvented water network. Participants expressed the low cost of water as significant barrier to reinforcing the true value of water. One participant expressed this sentiment by stating: "...people do not value anything that is cheap...", and suggested the use of rising block tariffs, as: "when it [water] costs more, people will consider water efficiency products more". In addition, it was suggested that WSPs should also consider alternative models of financing water efficiency products. 
Table 1. Real and hypothetical service innovation initiatives for water efficiency/the water sector (as highlighted by participants)

\begin{tabular}{|c|c|c|c|}
\hline Initiative & $\begin{array}{l}\text { Type (listed in } \\
\text { section 2) }\end{array}$ & Details/Outcomes (potential or actual) $^{1}$ & $\begin{array}{l}\text { Known impact to date } \\
\text { (stage of initiative) }\end{array}$ \\
\hline $\begin{array}{l}\text { Rainwater harvesting or greywater } \\
\text { reuse equipment leasing }\end{array}$ & $\begin{array}{l}\text { Rental/lease } \\
\text { agreements }\end{array}$ & $\begin{array}{l}\text { Reduction in potable water use, access to alternative sources, } \\
\text { reorientation from product to practice, changing social norms }\end{array}$ & N/A (hypothetical) \\
\hline Runoff capture and sharing & $\begin{array}{l}\text { Partnership } \\
\text { (social/community), } \\
\text { other }\end{array}$ & As above & N/A (pilot) \\
\hline Retail competition in Scotland & $\begin{array}{l}\text { Competition, } \\
\text { service }\end{array}$ & $\begin{array}{l}\text { Efficiencies in billing, smart metering reducing water use: } 5 \% \text { of } \\
\text { businesses switched supplier, but } 50 \% \text { renegotiated beneficial supply } \\
\text { terms }\end{array}$ & $\begin{array}{l}34 \mathrm{KtCO}_{2}, 16 \mathrm{bn} \text { litres water } \\
\text { saved (completed) }\end{array}$ \\
\hline Reverse auction & $\begin{array}{l}\text { Service, technical, } \\
\text { partnerships }\end{array}$ & $\begin{array}{l}\text { Ability to directly support implementation of customer-selected options to } \\
\text { improve source water quality, reduce polluted runoff and source control }\end{array}$ & $\begin{array}{l}\text { Fowey catchment - } £ 360 \mathrm{~K} \\
\text { distributed to farmers for } \\
\text { improvements on a value-for- } \\
\text { money basis (completed) }\end{array}$ \\
\hline Water efficiency retrofit & Technical & $\begin{array}{l}\text { Improving facilities and service delivery whilst achieving better water and } \\
\text { cost savings }\end{array}$ & $\begin{array}{l}35 \% \text { water savings (ongoing } \\
\text { calculations), positive guest } \\
\text { feedback, behaviour transfer to } \\
\text { home (completed: } 28 \text {-room } \\
\text { hotel) }\end{array}$ \\
\hline $\begin{array}{l}\text { Combining water \& energy efficiency } \\
\text { in Wales }\end{array}$ & $\begin{array}{l}\text { Partnerships, } \\
\text { targets, service, } \\
\text { technical }\end{array}$ & $\begin{array}{l}\text { Agreement between multiple water/energy stakeholders to provide } \\
\text { equipment for free if records of installations were maintained }\end{array}$ & $\begin{array}{l}£ 30 \mathrm{M} \text { spent across a } 6 \mathrm{~K} \text { home } \\
\text { uptake (completed: see } \\
\text { http://arbed.org/en/about-arbed } \\
\text { for more info) }\end{array}$ \\
\hline Enhanced service & $\begin{array}{l}\text { Service, pricing, } \\
\text { other }\end{array}$ & $\begin{array}{l}\text { Reduced price water efficiency fittings, quicker failure response times and } \\
\text { access to other services (flood protection \& SuDS) }\end{array}$ & N/A (hypothetical) \\
\hline Green tariff & $\begin{array}{l}\text { Service, pricing, } \\
\text { other }\end{array}$ & $\begin{array}{l}\text { Similar to energy companies - customers pay to support alternative water } \\
\text { supply system infrastructure (rainwater, greywater, wastewater reuse) }\end{array}$ & N/A (hypothetical) \\
\hline Service rather than product access & $\begin{array}{l}\text { Rental/lease } \\
\text { agreements }\end{array}$ & $\begin{array}{l}\text { Similar to services provided in the music streaming, transportation device } \\
\text { and floor covering industry -lease the associated service rather than the } \\
\text { product (CDs/cars-bikes/carpets) - water efficient fittings? }\end{array}$ & N/A (hypothetical) \\
\hline Examine ${\mathrm{B} 2 \mathrm{~B}^{*} \text { operations }}$ & Service, pricing & $\begin{array}{l}\text { Getting billing, metering and monitoring right is key - paying for } \\
\text { equipment? SI is solving these issues }\end{array}$ & N/A (ongoing) \\
\hline $\begin{array}{l}\text { Enhanced communication with } \\
\text { subsidised monitoring }\end{array}$ & $\begin{array}{l}\text { Service, technical, } \\
\text { customer } \\
\text { engagement }\end{array}$ & $\begin{array}{l}\text { Already undertaken by some energy companies to facilitate low daily } \\
\text { consumptions }\end{array}$ & N/A (cross-sectoral) \\
\hline Rising block tariff & Service, pricing & Including threshold allowance for certain segments & N/A (proposed) \\
\hline
\end{tabular}


3.1.4 Q4. Focusing on a wide range of services, such as staying in hotels, buying food or going to the doctors; can you think of examples of ways in which services are provided that you feel are innovative?

Participants provided existing examples of innovation in other sectors, such as: high fidelity music rental via internet streaming; short-term vehicle rental (bikes and motor vehicles) and floor cover leasing, as opposed to buying a carpet. These examples followed a common theme of accessing a service instead of a product. In addition, examples of innovation followed an efficiency theme, such as: touchscreen patient arrival to avoid queuing; free time-limited $\mathrm{Wi}-\mathrm{Fi}$ and countdown buzzers to alert and placate hungry (infant) diners.

\subsubsection{Q5. Returning to our focus on water efficiency, please try to design your own definition of service innovation}

All participants struggled to design their own definition, instead preferring to suggest requisite components of a SI definition. The components have been grouped into broad themes, labelled Fundamentals, Cost and Collaboration and are shown in Table 2.

In summary, all participants agreed that WSPs already provide high quality water through an effective distribution network, which did not require innovation per-se. The overwhelming message was that WSPs, in innovating, need to focus on business fundamentals. These include billing, customer relations and improved provision of data and its visualisation. It was apparent that the customer should be the beneficiary of the result of any SI and therefore elements of SI should orientate around enhancing the provision of services to them. In interpreting these discussions, the authors visualised this interaction as being a tree, with the customer as the trunk and the SI initiatives as the branches (Fig. 2). This is in contrast to the typology presented in Fig. 1, which locates technological options at the junction of concepts, interfaces and delivery systems. However, these processes are still fundamental to achieving $\mathrm{SI}$ in the tree-branch model, as some of the options suggested represent interfaces (customer relations, data visualisation) and delivery systems (billing, information services), which may or may not require technology to support them.

Additionally, most participants agreed that the energy sector could provide a blue print for the water sector to learn from, particularly with respect to customer relationship management and providing consumptive data in line with initiatives described at the end of Section 1.1. These have also been added to Fig. 2. Furthermore, the low financial cost of water was identified as a barrier to engaging people with water efficiency. This barrier was identified by participants and all largely agreed an alternative pricing required further investigation and testing. The final question, asking participants to suggest a definition of SI, was in hindsight a very challenging question. However, all participants provided elements of such a definition, which enabled the working definition to be further developed. Participants kindly provided insightful data, however the volume of data was lower than anticipated. A low participation rate, due to a myriad of reasons, is common in research. In this instance it is hypothesised that the low rate could be attributed to the emergent concept of innovation protectionism, as previously discussed.

\subsection{Innovation Protectionism or Protecting Intellectual Property?}

As briefly mentioned previously, a further concept that was elucidated though the informal conversations with potential participants is that which the authors have termed 'innovation protectionism'. The main feature of this concept is that a SI (or other initiative) exists, but the owners of the initiative are reluctant to share or disseminate information about it before they themselves have. This concept emerged initially as a way of explaining the low survey and case study participation rate. Through discussion it then became apparent that it was a wider phenomenon than has perhaps been documented in the innovation literature to date. It is understandable that the owners of a perhaps novel or previously untrialed initiative would be reluctant to release information into the public domain before they have had a chance to release such information. It is also a process that would probably parallel the protection of intellectual property that has not been formally protected via a patent, copyright or other mechanism of 'know how' registration. However, the practice of innovation protectionism could 
result in the impeded and delayed diffusion of innovation, which is a recognised problem within the water sector. For example, innovation activity in water-related technologies has been increasing over the last two decades; however there is a bias towards supply-side technologies [12]. Indeed, a special volume of the Journal of Cleaner Production, due for publication in March 2016, will focus on the 'dynamics of water innovation' to document the application of a range of innovations in ICT, structural change, learning and strategizing, competence and capacity building and social innovation [13], within the water sector and between the water sector and other sectors. Additionally, a recent European Commission report [14] identified that a significant barrier to innovation is the widespread reluctance to trial new initiatives. It may be that trials are being undertaken, but are not being widely publicised due to innovation protectionism or fear of losing rights or ownership of unprotected intellectual property (ideas/ initiatives). This echoes standard WSP practice, where techniques and data may be for internal use only and not shared across the sector, often leading to a number of different processes for achieving the same goal or objective.

\subsection{Refining the SIfWE Definition - What, Where, Who?}

This paper began by suggesting a working definition for SIfWE of: "Service innovation for water efficiency represents the concepts, clients, delivery systems and technological options available to the water sector through which to develop new or improved service functions resulting in an enhanced customer experience and requiring structural organisational change." However, the results guided the definition from a narrow focus on water efficiency toward a more holistic view of SI. Accordingly, a refined definition is proposed:

"Service innovation for the water sector places the WSP customer as the focus of service innovation. The customer is both the catalyst and recipient of transformative change in concepts (ideas and initiatives, such as alternative tariffs, data visualisation), technological solutions (especially ICT), delivery systems (for example accurate billing, email, instant messaging) and supple organisational structures (for instance responsible processes, people and teams). Service Innovation enables the customer to select the appropriate options to enhance their experience, leading to a valued integrated water management service".

The 'what' is represented by the concepts and initiatives, the 'where' is represented by the WSPs and organisational structures and the 'who' is represented by WSP customers who are the focus of SI concepts, initiatives, interfaces and delivery systems. However the proposed definition cannot be the 'final' word. Definitions should always change and evolve in response to new knowledge, ideas and context. Additionally, the triangulation of the findings highlighted that SI should not focus solely on water efficiency, for example service enhancements could be realised through improvements in many aspects of the water management process.

\subsection{Beyond Service Innovation for Water Efficiency}

It is also useful to situate $\mathrm{SI}$ in the wider sustainability transitions movement that is being commented on in the urban water sector [15]. These are often focussed on transition occurring within the WSP rather than looking at the wider hydro-social contract that WSPs have with the community. From a water efficiency perspective, the move from a supply-led to demand-led planning paradigm has shaped much of the water resources planning in the UK based on a twin track approach. In parts of Australia, the need for more integrated water management has led to the concept of water sensitive cities and the transition towards these is based on sociopolitical drivers and service delivery functions. Although not explicit features of the water cycle/water sensitive city, there is a need for cross-sectoral SI in order to deliver new decentralised sources and to reinforce water sensitive behaviours [16].

A further conceptual approach incorporating elements of SI has been presented by Sydney's Institute of Sustainable Futures [17]. This associates the relative cost per household of water infrastructure provision with a certain generation of water infrastructure (Fig. 3). The third generation in particular focuses on alternative but centralised supply options such as desalination or wastewater reuse. In Australia, the high cost associated with such options was justified by the short time-frame in which to make planning decisions to address the Millennium Drought (1995-2012). However, the fourth generation focuses on integrated service provision and customer service, with the aim of 
meeting multiple objectives. For example, green infrastructure could be regarded as fourth generation as it can deliver water saving, stormwater management, heat island mitigation and health benefits, which have been realised in projects such as the Olympic Park in London [18].

Considering how SI fits within fourth generation infrastructure provision enables us to think beyond services provided directly to the customer. An example of this is innovative permitting and licensing, where discharges from treatment works to receiving water bodies are controlled based on dynamic risk-based operational variables depending on a range of indicators rather than set levels. Such practices are Sls that allow the needs of the customer and the environment (both requiring good water quality to survive) to be met, potentially with a lower cost (monetary and energy/carbon) [19]. Whilst not directly implemented at the customer or building-scale where water efficiency products would be, these approaches still enable water to be treated and used more efficiently than under current practice.

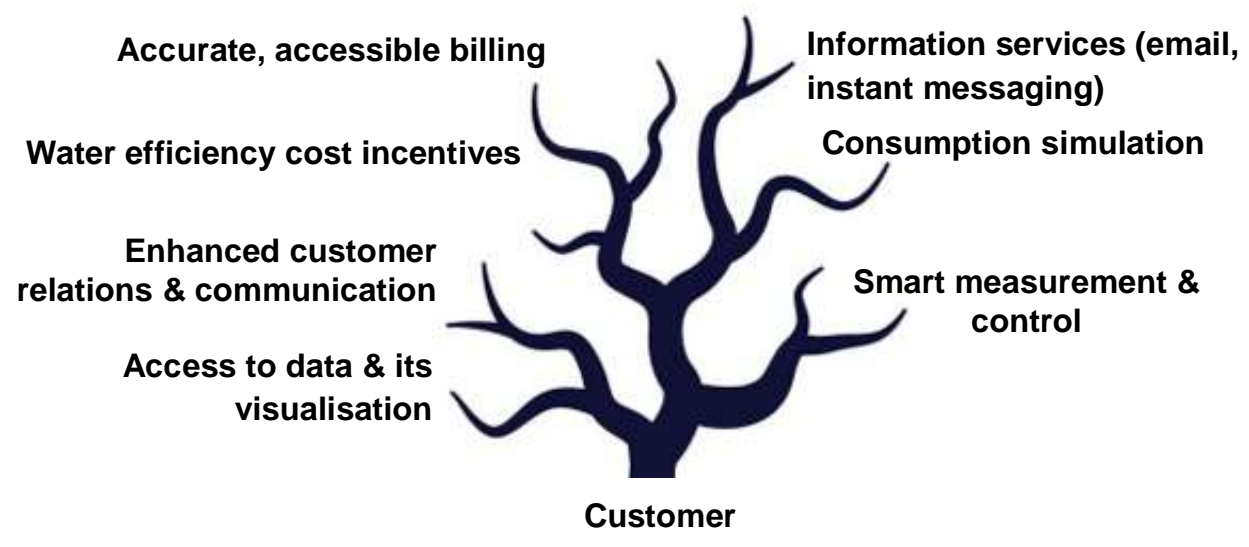

Fig. 2. The tree-branch model of SI for the water sector

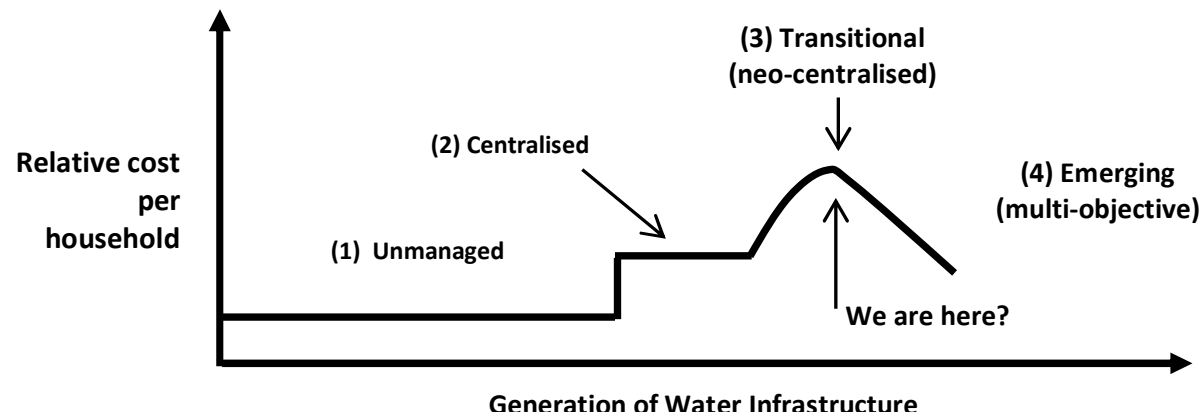

Fig. 3. The 'Four Generations of Water Infrastructure' and their associated relative cost per household (adapted from [17])

Table 2. Key phrase components given by participants for a working definition of SI

\begin{tabular}{lll}
\hline Fundamentals & Cost & Collaboration \\
\hline Better communication & A true cost of water reflected & $\begin{array}{l}\text { Integrated water } \\
\text { management }\end{array}$ \\
$\begin{array}{l}\text { Monitoring \& measurement } \\
\text { Improved access to WSP }\end{array}$ & Water efficiency cost incentives & \\
\hline
\end{tabular}




\section{CONCLUSION}

The Water Act will (from 2017) enable wholesaleretail separation and in turn, should create competition in the market. From the present day and in the future, Water Service Providers (WSPs) will be challenged on services other than the supply and cost of water (the product). Retail competition is unlikely to result in a lower-cost price war between WSPs and therefore service innovation (SI) offers WSPs an alternative way to retain and recruit new customers.

SI has previously been a loosely-defined and slightly intangible concept, but the research presented in this paper has led to an empirically derived revised version for the water sector. Case study information and interview discussions revealed that the water sector is perceived as operating a high quality infrastructure and delivering an exceptional product. In addition the water sector offers scope for improvement in fundamental business services. These include billing, customer relations, communication (information services) and data provision and visualisation. A tree-branch model of SI is suggested, emphasising the placement of the customer as the focus of $\mathrm{SI}$ and a revised definition of SI has been developed in order to assist WSPs in enhancing the services provided to their customers. The definition is: "Service innovation for the water sector places the WSP customer as the focus of service innovation. The customer is both the catalyst and recipient of transformative change in concepts (ideas and initiatives, such as alternative tariffs, data visualisation), technological solutions (especially ICT), delivery systems (for example accurate billing, email, instant messaging) and supple organisational structures (for instance responsible processes, people and teams). Service Innovation enables the customer to select the appropriate options to enhance their experience, leading to a valued integrated water management service." Future discussions on and research relating to SI should focus on cautiously elucidating lessons from parallels with the deregulation of the energy industry and other sectors in which clearly defined SI has yielded success. Additionally, further social sciencebased research is warranted to investigate what is important to non-domestic customers and how they would visualise an enhanced service from WSPs. Developing this understanding would enable WSPs to innovate accordingly.

\section{ACKNOWLEDGEMENTS}

The authors would like to thank all those who shared their time and knowledge in the research undertaken for this paper.

\section{COMPETING INTERESTS}

Authors have declared that no competing interests exist.

\section{REFERENCES}

1. HM Government (2014) Water Act 2014. Available:http://www.legislation.gov.uk/ukp ga/2014/21/pdfs/ukpga 20140021 en.pdf (Accessed 09-01-15)

2. Ofwat. Innovation priorities for the water sector. Water sector innovation leadership group report. Crown Copyright; 2011. Available:http://www.ofwat.gov.uk/regulatin g/pap pos1105innovpriorities.pdf (Accessed 09-01-15)

3. CCWater. Unchartered waters: Nonhousehold customers' expectations for competition in the water industry qualitative research findings. Report by Accent for CCWater, Presentation; 2014.

Available:http://www.ccwater.org.uk/wpcontent/uploads/2014/06/UnchartedWaters-Non-household-customersexpectations-for-competition-in-the-waterindustry1.pdf

(Accessed 09-01-15)

4. Dŵr Cymru Welsh Water (2016) Company Information.

Available:http://www.dwrcymru.com/en/Co mpany-Information/Dwr-Cymru-Welsh-

Water.aspx

(Accessed 22-03-16)

5. PWC. Managing AMP6 incentives \& penalties: Putting outcomes at the heart of your business; 2016.

Available:http://www.pwc.co.uk/industries/ water/insights/managing-amp6-incentivespenalties.html

(Accessed 22-03-16)

6. Miles I. Services in the new industrial economy. Futures. 1993;25(6):653-672.

7. Den Hertog $P$, Bilderbeek $R$. Conceptualising service innovation and service innovation patterns. Report to the research programme strategic information provision in innovation and services (SIID) for the Ministry of Economic Affairs, 
Directorate for General Technology Policy; 1999.

8. Van Ark B, Broersma L, den Hertog P. Services innovation, performance and policy: A review. Research Series No. 6, Directorate-General for Innovation, Ministry of Economic Affairs, The Hague; 2003.

9. European Commission (2013) Guidebook Series: The Smart Guide to Service Innovation.

Available:http://ec.europa.eu/enterprise/pol icies/sme/regional-sme-

policies/documents/no. 4 service innovatio n en.pdf

(Accessed 22-05-15)

10. Information Technology for European Advancement (2007) Innovation report: services-oriented platform provides new approach to residential energy sector. ITEA Project SHOPS.

Available:https://itea3.org/project/result/do wnload $/ 5580$

(Accessed 22-05-15)

11. Robson C. Real world research. Blackwell, Oxford; 2002.

12. OECD. Invention and international diffusion of water conservation and availability technologies: Evidence from patent data. Working Party on Climate, Investment and Development, Environment Policy Committee, Environment Directorate; 2014.

13. Wehn U, Montalvo C. The dynamics of water innovation. Special volume Call for Papers for the Journal of Cleaner Production, Elsevier; 2014.

Available:http://www.journals.elsevier.com/ journal-of-cleaner-production/call-forpapers/the-dynamics-of-water-innovation/ (Accessed 09-01-15)

14. European Commission. Future brief: Innovation in the water sector. EC Report; 2015.
Available:http://ec.europa.eu/environment/i ntegration/research/newsalert/pdf/innovati on european water sector FB10 en.pdf (Accessed 22-05-15)

15. Bell S, Ward S, Butler D. Retrofitting sustainable integrated water management at household, building and urban scales. IN: Dixon, T., Eames, M., Hunt, M. and Lannon, S. (eds) Urban Retrofitting for Sustainability: Mapping the Transition to 2050. Routledge, Abingdon. 2014;221233.

16. Brown R, Keath N, Wong T. Transitioning to water sensitive cities: Historical, current and future transition states. Proceedings of the $11^{\text {th }}$ International Conference on Urban Drainage, Edinburgh; 2008.

Available:http://web.sbe.hw.ac.uk/staffprofi les/bdgsa/11th International Conference on Urban Drainage CD/ICUD08/pdfs/618 .pdf

(Accessed 09-01-15)

17. White S, Turner A. Sustainable water futures: Integrated supply demand planning. Institute of Sustainable Futures' Master Class - Global Trends in Water Efficiency. University of Technology Sydney; 2014.

Available:http://www.watefnetwork.co.uk/fil es/default/resources/Virtual master 06-

13/StuartWhiteWaterEfficienc.pdf

(Accessed 09-01-15)

18. Foreign and commonwealth office. Going for green - Parkland in the Olympic Park. F\&CO YouTube Channel; 2010.

Available:https://www.youtube.com/watch? $\mathrm{v}=4 \mathrm{~V}-\mathrm{NB} 2 \mathrm{v} 6 \mathrm{zl}$

(Accessed 04-04-2013)

19. Meng F, Fu G, Butler D. Incorporating cost-effectiveness analysis into effluent permitting through integrated urban wastewater system modelling and multiobjective optimisation. Proceedings of the $13^{\text {th }}$ International Conference on Urban Drainage 2014, Kuching, Malaysia, September 7-12; 2014.

(c) 2016 Ward et al.; This is an Open Access article distributed under the terms of the Creative Commons Attribution License (http://creativecommons.org/licenses/by/4.0), which permits unrestricted use, distribution, and reproduction in any medium, provided the original work is properly cited. 